\title{
Geochemical and petrographic analysis on the stones and integrated digital survey of the Cathedral of Sant'Antioco di Bisarcio (Ozieri, Italy)
}

\author{
Stefano Columbu* \\ Dipartimento di Scienze Chimiche e \\ Geologiche \\ Università di Cagliari \\ Cagliari, Italy \\ columbus@unica.it \\ *Corresponding author
}

\author{
Marco Lezzerini \\ Dipartimento di Scienze della Terra \\ Università di Pisa \\ Pisa, Italy \\ marco.lezzerini@unipi.it
}

\author{
Giorgio Verdiani \\ Dipartimento di Architettura \\ Università di Firenze \\ Firenze, Italy \\ giorgio.verdiani@unifi.it
}

\begin{abstract}
The medieval Cathedral of Sant'Antioco di Bisarcio is one of the most important Romanesque churches in Sardinia. The countryside church is located on a volcanic hill in the area of Chilivani (Ozieri, north Sardinia). It was built with local Eocene-Miocene pyroclastites at the beginning of the XI century by Tuscan-Lombard workforce, according to three constructive phases, which reveal specific features both in terms of architecture and in relation to the use of building materials, represented by several pyroclastic rocks.

The collected results of geochemical-petrographic analysis on the volcanic rocks and 3D Laser Scanner survey of ancient building, together with a historical research, have shed light on the provenance and alteration of geomaterials, the evolution and the mutilations suffered by the church at later times; among these it can be distinguished the opening of a mullioned window, which was the starting point of our specific focus on the elements of the capital and the original "pulvino". The study of these elements was conducted through surveys and digital photogrammetry techniques.
\end{abstract}

Keywords-chemical analysis, XRF, Medieval, Romanesque, archaeometry, laser-scan, photogrammetry

\section{INTRODUCTION}

The ancient cathedral of Sant'Antioco di Bisarcio (Fig. 1) is located near the homonym medieval village (today in a state of ruin and not well observable), near the North-West edge of the Chilivani plain, on a volcanic plateau that slopes into leaps on the plain itself, separating it from the Anglona with the heights of Su Sassu and Su Sassittu.

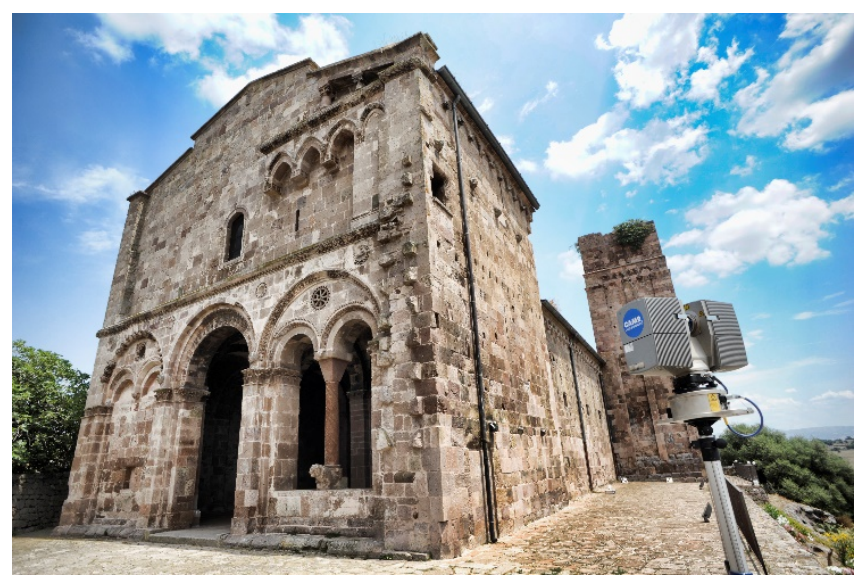

Fig. 1. The 3D Laser Scanner at work along the perimeter of the Church.
The region was densely inhabited since antiquity; there are numerous testimonies of the Neolithic and Nuragic age in the extreme part of the plateau guarding the wide plain below, nodal point also in Roman age of the road artery that connected Civita with Turris Libisonis, and that from Anglona it led towards the central Logudoro and then towards the Barbagie of central Sardinia. In addition to the architectural aspects, the Romanesque church of Bisarcio has also been studied for its importance as the seat of the Diocese [1], which is divided into three distinct geographical areas, Anglona, Oppia, Monteacuto Inferiore.

The year of foundation of the Cathedral is not known exactly. However, by a document dated 1112 where the destruction of the Church caused by fire is indicated (probably occurring no later than 1090 [1]), its first construction must certainly be traced back to a previous period. The source cited is a fragment of the renewal card of a donation made by the judge of Torres Costantino I and his wife Maria de Serra in favor of the church of Bisarcio (Tola, XII century [2]).

The church presents only portions of the original cathedral, in the South and North sides of the present presbytery and in the single window, made with irregular (simply rough) blocks $(<20 \mathrm{~cm})$ of local pyroclastic rocks with a degree of welding from medium to high, belonging to the first volcanic phase of Sardinia (Eocene-Miocene; 38-15 $\mathrm{Ma}$ ). The primitive façade, initially a tympanum is probably attributed to Pisan workers.

The new church was rebuilt on the ruins of the former around 1150 [3] by the judge of Torres Gonnario II de Lacon Gunale [4], and it was probably consecrated by a papal legate in 1174 with other churches of the Turritano [1]. Throughout the thirteenth century, there is no direct news about Bisarcio, it is possible to find only attestations of his bishops, who appear as witnesses in acts of giving or exchanges of servants.

The Cathedral was built with pyroclastic rocks belonging to the Eocene-Miocene magmatic phase.

The volcanic rocks are widely used in the Romanesque architecture [5-11], as well as, in the sardinian Cultural Heritage from other historical periods [12-14].

To define the origin of construction materials, the samples collected in the field outcrops and taken from the monument have been studied by petrographic analysis and XRF spectrometry on major and trace elements. XRF analytical 
data together XRD analysis results have been also used to define the chemical and mineralogical alteration of the volcanic stones and the secondary phases present in their surface. Furthermore, the whole ancient building and its surrounding area were surveyed with the following methods: photography, 3D Laser Scanner for the whole interior and exterior parts, micro-photogrammetry of stone surface. All data were treated and analyzed to evaluate the most significant structural, geometric and architectural aspects of the Cathedral. The petrographic investigations on construction materials [15-19] together with the 3D laser scanner survey of the artifact [20-22] are very significant in order to identify the origin of the raw materials (and eventually the ancient quarries) and to recognize the construction phases of the monument.

\section{GeOlOGiCAL SETTING}

The volcanic rocks, which have been used as construction materials in the St. Bisarcio church, belong to the significant Sardinian Late Eocene-Miocene orogenic magmatic phase occurred between 38 and 15 Ma [23, 24]. The volcanic activity leds to emplacement of tholeiitic, calcalkaline, shoshonitic and ultrapotassic products, mainly along the Sardinian Oligo-Miocene rift, a large tectonic pit, which structure crossing Sardinia [25-27], with a peak during the 22-18 Ma time range [28]. Since that time, in various Sardinian areas, especially along the western graben, a highly explosive fissural activity, with simultaneous and alternating emissions of basaltic and andesitic lavas, produced abundant pyroclastics and dacitic-rhyolitic rocks.

The pyroclastic rock (Fig. 2) used for constructing the Cathedral can be attributed to this latter volcanic activity $(21.2 \pm 0.8$ My [29], locality S. Antioco of Bisarcio). Epiclastic rocks, occasionally used in masonry for decorative purposes together with small amounts of green sandstone, occurs to a lesser extent in the area.

Field surveys conducted for the purpose of identifying the rocks used for construction of the Cathedral, in agreement with several other authors [29], pointed to the presence of vast pyroclastic flows with strongly variable geochemical composition. These rocks were also compared with the pyroclastic rocks outcropping in the nearest and easternmost Oschiri area, already studied by Columbu et alii [30].

Based on their volcanological, petrographic and geochemical features, the samples were divided into three main groups: 1) welded pyroclastic rocks (including lava-like ignimbrites) from the Chilivani area (WPC); 2) unwelded pyroclastic rocks again from Chilivani (UPC); 3) pyroclastic rocks from the Oschiri area (OP).

\section{MATERIAL AND METHODS}

A. Geochemical and petrographic characterization of stone

Petrographic determinations of mineralogical composition were carried out on polished thin sections by optical polarised microscope Leitz Wetzlar.

Chemical analyzes on bulk rock were determined by XRF with spectrometer Philips PW1400 using a Rh-tube for the analysis of major elements and some trace elements $(\mathrm{Rb}$, $\mathrm{Sr}, \mathrm{Pb}, \mathrm{Zn}, \mathrm{Y}, \mathrm{Nb}$ and $\mathrm{Zr}$ ) and a W-tube for the analysis of the elements $\mathrm{Ni}, \mathrm{Cr}, \mathrm{Ba}, \mathrm{V}, \mathrm{La}$ and $\mathrm{Ce}$.

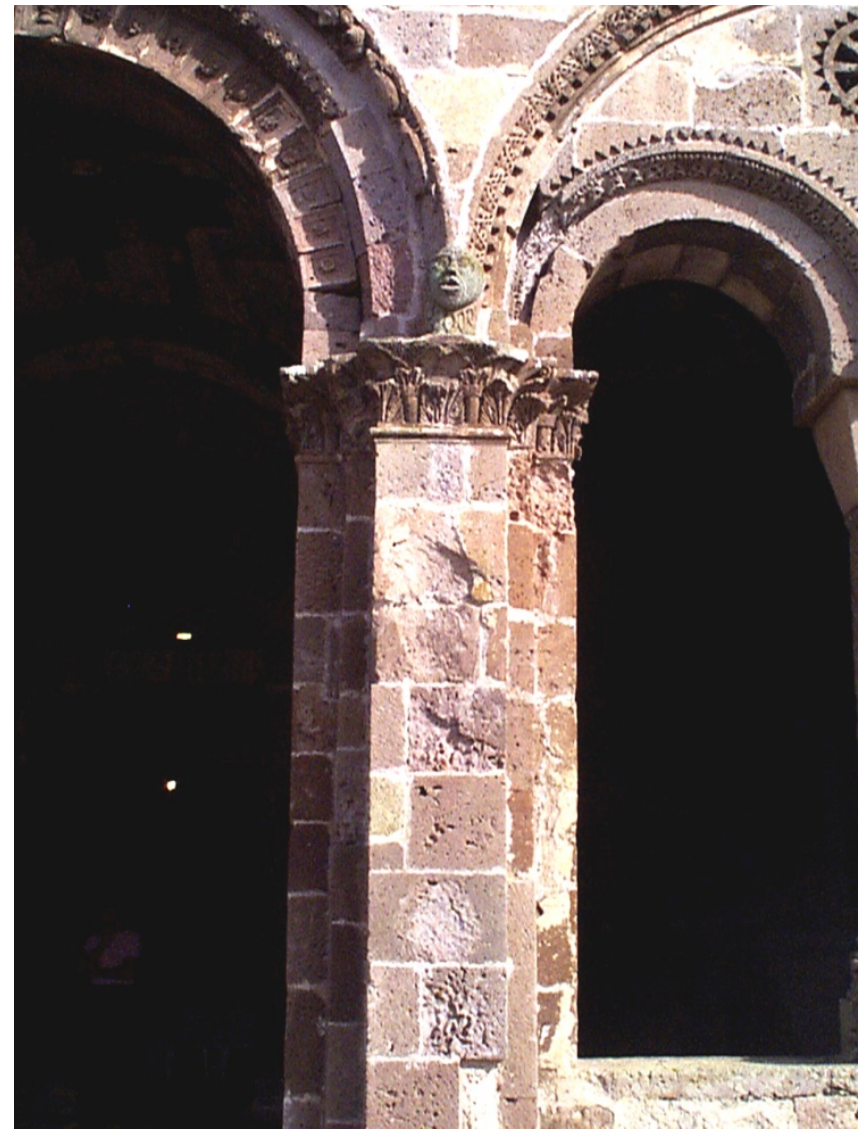

Fig. 2. Worked and squared pyrocastites ashlars in left side of the bifora in main façade of the Cathedral.

The analyses were carried out on pads of rock powders (with a diameter of $35 \mathrm{~mm}$, approximately), previously treated with polyvinyl alcohol, on a metal support of cylindrical shape compressed to 13 tons. The reduction of the data relating to elements more was obtained according to the methodology of Franzini et alii [31], while that of the trace elements using the method of the fundamental parameters according to Criss and Birks [32] modified by C. Garbarino (unpublished data). For calibration of major and trace elements were used over 30 international standards of reference.

The measurement accuracy is $\pm 1 \%$ for $\mathrm{SiO}_{2}, \mathrm{TiO}_{2}$, $\mathrm{Al}_{2} \mathrm{O}_{3}, \mathrm{Fe}_{2} \mathrm{O}_{3}, \mathrm{CaO}, \mathrm{K}_{2} \mathrm{O}$ and $\mathrm{MnO}$ and $\pm 4 \%$ for $\mathrm{MgO}, \mathrm{Na}_{2} \mathrm{O}$ and $\mathrm{P}_{2} \mathrm{O}_{5}$. The detection limits are about $3 \mathrm{ppm}$ to $3 \sigma$ for most of the elements; the accuracy of trace elements is $\pm 2 \div$ $3 \%$ to $1000 \mathrm{ppm} ; \pm 5 \div 10 \%$ at $100 \mathrm{ppm}$ and $\pm 10 \div 20 \%$ to $10 \mathrm{ppm}$. The loss for calcination (L.O.I.) was determined by calculating the loss in weight $\%$ at $1100^{\circ} \mathrm{C}$, while the $\mathrm{FeO}$ was determined by volumetric titration with $\mathrm{KMnO}_{4} 10 \mathrm{~N}$ in acid solution.

Classification of the volcanic rocks and relative nomenclature was carried out according to De La Roche et alii [33] diagram, because it was considered the most appropriate for the classification of these pyroclastic rocks.

To determine the qualitative / semi-quantitative mineralogical composition of powdered samples, X-Ray Powder Diffraction technique (XRPD) was applied to the sampled volcanic rocks, belonging to both the monument and field volcanic outcrops. 


\section{B. Digital 3D laser scanner survey}

For 3D laser scanner survey the operations were conducted using a Cam/2 Faro Photon unit, with a measuring range up to 80 metres. This range was quite enough for all the operative conditions. All the materials in the churches gave a very good response to the 3D laser scanner signal [34]. A special attention has been dedicated to the planning of the scanning positions, to reduce the number of the scans to the minimum needed to reach an appropriate coverage of the building, with a well descriptive result.

After the completion of the 3D laser scanner survey the following phases of data treatment were brought on: the alignment (done using Cam/2 Faro Scene), the optimization (with the cleaning of any remaining trace of anomalous set of points and the removal of possible large duplicated overlapping area), the extraction and exporting of data towards other software.

Once this first part of the post processing was completed, the following task was the $2 \mathrm{D}$ drawing production, this was done to expand the usability of the datasets: plans, sections and fronts are typical solutions. The processing of the data for $2 \mathrm{D}$ drawings creation is done extracting partial and section views from the aligned pointcloud, exporting them in bitmap format (most of the time using TIF format) and then importing them in Autodesk Autocad. In the CAD software the bitmap is scaled to $1: 1$ visualization and then used as a base for creating the vectorial drawing. Such a processing benefits only partially from the full quality and level of detail of the pointcloud, but with a representation aimed to produce 1:50 drawings this issue is marginal. The quality and accuracy of the resulting drawing are superior in front of any previous representations. The state of the monument, in its condition at the time of the survey is digitally archived.

\section{Photogrammetry investigations}

The photogrammetric survey was done using a professional digital SLR, a Nikon D700, with a resolution of 10.3 Megapixel and a full frame sized sensor equipped with a Micro Nikkor MF 55mm F2.8 lens, this lens is well known for its quality and the capacity to create very sharp and accurate images. The capacity to reach a minimal distance with the subject made this lens extremely versatile to take close-up of details [35]. Without the need of any add-on accessory, the $55 \mathrm{~mm}$ lens can reach the 1:2 reproduction factor. The focal length of the lenses allows a good depth of field even at 1:1 reproduction scale, stopping down from F8, thus, this lens allows to stop down the diaphragm to F32 with a significant increase in the depth of field, generating a larger number of usable pixel in the photogrammetry process. This lens has a quite pronounced perspective and this helps the photogrammetric software.

The software used for all the photogrammetric operations was Agisoft Photoscan, a well developed program based on the Structure from Motion / Image Matching (SfM/IM) procedure [36]. The process was completed following the classic process of alignment, dense cloud generation, mesh generation, texture generation and, in the end, model scaling according to the data of the 3D laser scanner survey.

\section{RESULTS AND DISCUSSION}

\section{A. Mineralogical, geochemical and petrographic characterization}

About one hundred chemical analyses have been performed by XRF spectrometry on major and trace elements of volcanic samples collected in the field outcrops and taken from the church itself. According to De La Roche et alii [33] (Fig. 3), the WPC rocks have been classified as quartz-latite, the UPC (field samples) as rhyolite, rhyodacite and rare quartz-trachite, the UPC (samples from the church) as rhyodacite, rhyolite, alkali-rhyolite and subordinately of quartz-latite and quartz-trachite. In agreement with Columbu [30], the pyroclastic rocks from the Oschiri area (OP) vary from subordinate rhyodacite to abundant rhyolite with minor amounts of quartz-latite and quartz-trachite.

Observing the analytical data, some differences in geochemical characteristics have been highlighted between the different individuated areas. The pyroclastites from Chilivani (WPC) and Oschiri (OP) areas show on average lower $\mathrm{K}_{2} \mathrm{O}$ and higher $\mathrm{TiO}_{2}, \mathrm{Al}_{2} \mathrm{O}_{3}, \mathrm{FeO}_{\mathrm{t}}, \mathrm{Na}_{2} \mathrm{O}$ concentrations than the UPC pyroclastites, as well as, slightly lower $\mathrm{Zr}, \mathrm{Nb}, \mathrm{Y}$, La and Ce amounts.

Also in microscopic features it is possible to observe some differences. The WPC rocks have a porphiritic structure for phenocrysts of (in order of segregation) spinel, plagioclase, clinopyroxene, K-feldspar, quartz and very rare horneblende. Under petro-volcanological point of view, they show strongly variable features, characterised by a variable porphyritic index (from 4 to $18 \%$, in some cases even within the same cooling unit of volcanic flow), rare (or absent) welded pumic, more or less presence of welded lapilli and variable amount $(2-8 \%)$ of angular / rounded cognate fragments. Sometimes, gabbro nodules or granoblastic fragments of the crystalline basement are present.

The unwelded pyroclastic rocks (UPC) show a different paragenesis, characterised by phenocrysts (in order of segregation) of spinel, plagioclase, \pm orthopyroxene, clinopyroxene, \pm biotite, K-feldspar and quartz. Regarding the petro-volcanologicl aspects, the UPC show greater variability, especially for the pumice, and subordinately also for the incidence of phenocrysts and lithic fragments.

As regards the alteration processes, we can observe some changes in the original paragenesis as function of different petro-volcanological characteristics of volcanic stones.

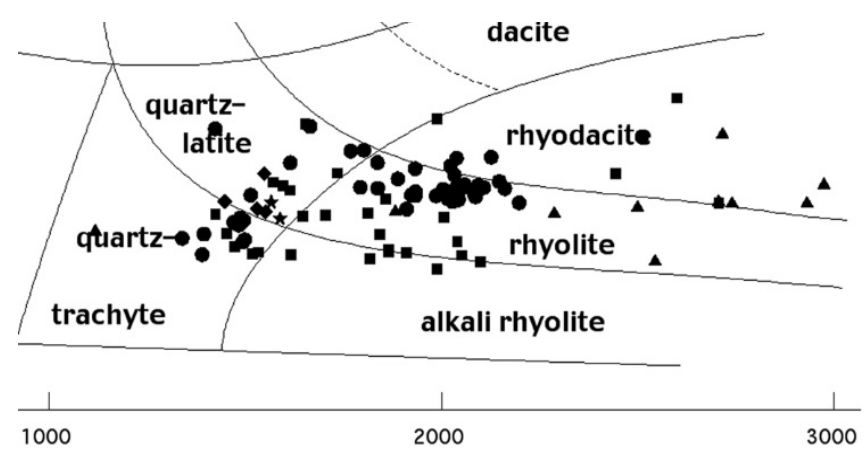

Fig. 3. Classification diagram of De La Roche et alii ([33] modified). Stars $=\mathrm{WPC}$ (field campaign); triangles $=\mathrm{UPC}$ (field campaign); rhombi $=\mathrm{WPC}$ (church); squares = UPC ( church); circles = OP 
Thus, these process leads to an alteration of the mineral assembly. According to the results of X-ray diffraction analyses (XRD), silica phases (i.e. opal-CT), hematite, zeolite (i.e. mordenite), and phases of chlorite group (as partially mineralogical transformation of rare biotite) have been observed. Unlike what is observed by other authors [37], XRD analysis do not show the presence of clinoptilolite, found in other parts of Sardinia.

\section{B. $3 D$ digital survey on the monument}

The digital documentation is a strategic part in the construction of a proper knowledge base of an architecture. In the project, for this Church, a set of three different digital surveys were planned: global digital survey of the architecture using a 3D laser scanner unit (Figs. 4 and 5); photogrammetry of a selection of significant details; photogrammetry in place of a set of material samples [38]. The intention was to produce an archive of information at the same time practical and well-fitting to traditional procedures. The St. Antioco di Bisarcio Cathedral has a quite large size, with an articulated separation of the spaces, some ruins in the nearby and is quite high in front of the free space around. If the documentation of a generous area around the church was strategic for a clear description of the architectural environment, at the same time it was very important to have a high level of details, with clear description of significant details, diversification of materials and parts. To fully accomplish the premises of creating a well working archive for documenting the state of the monument, there was the need to have a level of detail capable to describe the state of all the surfaces, not only macroscopic pathologies and alterations, but also incoming and developing transformation from the original condition [38].

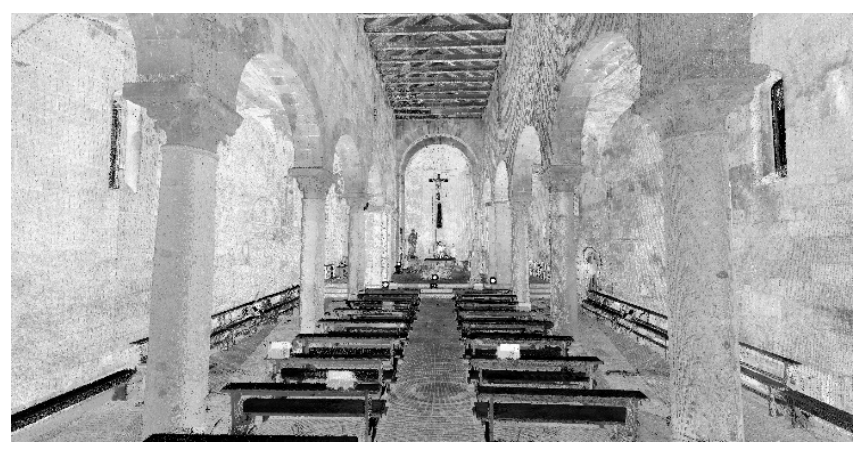

Fig. 4. Aligned pointcloud produced by the 3D Laser Scanner, internal view of the Cathedral.

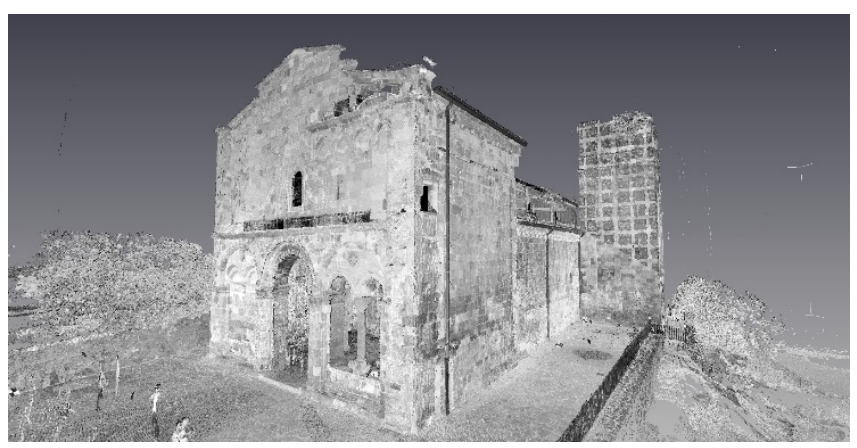

Fig. 5. Aligned pointcloud produced by the 3D Laser Scanner, external view of the Cathedral.
At the state of the art of the technologies it is impossible to have such a level of details from a single survey work. A 3D laser scanner allows to gather massive amount of data, but it makes no sense to ask for a density of the measured points going behind the specific accuracy allowed by the tool in use. This means, in example, that when the 3D laser scanner in use has an accuracy of two or four millimetres, it is not a good idea to set a scanning density with a resulting grid minor than the accuracy itself. If done, the result will present surfaces described with a "noise" confusing the position of all the points, and not with a higher level of details. But even in the quite difficult hypothesis of having partial or complete high level of details from a single tool, the lack of a planning about the density of the final dataset may result in longer acquisition time and even more longer post processing. In this way, the optimal choice is the use of different tools, well combined. Each tool working at its best performance in terms of quality and speed. The operations started from the $3 \mathrm{D}$ laser scanner and further using the photogrammetry.

\section{Photogrammetry of artworks and surface samples}

The Cathedral has its specific set of unique elements: capitals, decorations, statues, and sculptures. They are meaningful and useful to understand and catch the story and value of the place. For some of these elements a detailed survey was planned to get a superior accuracy than the one obtained using the 3D laser scanner, the choice has been the one to make a specific photogrammetric survey of these elements. In the Cathedral, this investigation was operated for two elements: the statue of a lion (Fig. 6), placed as base of the main column in the entrance porch and for the capital of this same column (Fig. 7), removed during the previous restorations and now preserved in the local musem.

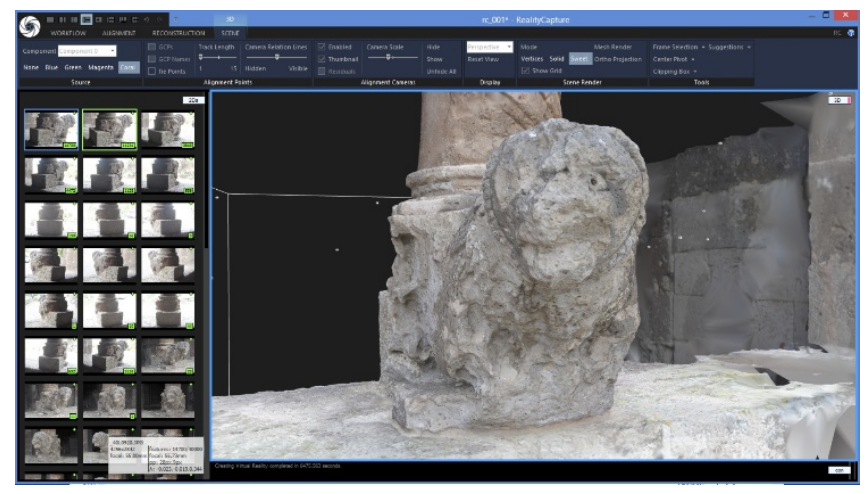

Fig. 6. Photogrammetry of the statue of the lion from the porch.

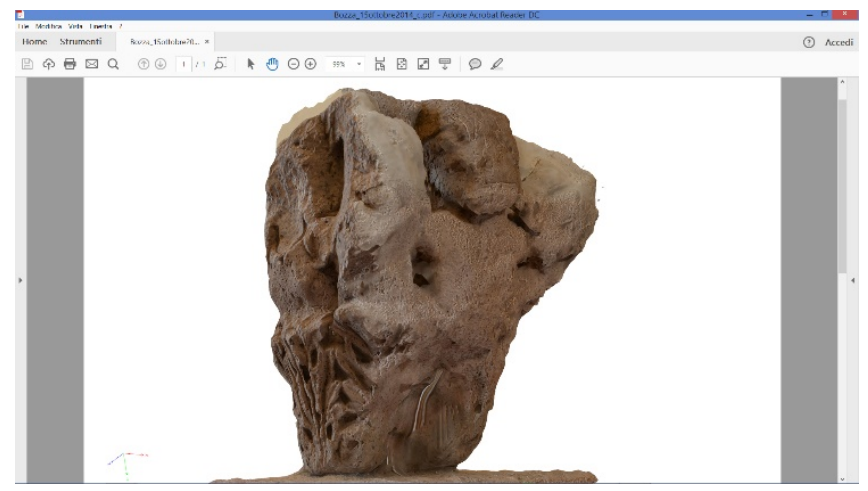

Fig. 7. Photogrammetry of the capital from the porch, test version exported in Acrobat PDF 3D. 


\section{Photogrammetry of surface samples}

To interpret and understood the characteristic of the stones used in this Romanesque Church, a series of samples were digitally taken from the church (in number of about 10; Fig. 8). To extend the set of documented materials and to reduce the need of direct physical sampling, the investigation about the geomaterials has been extended on the digital survey plane. This was done first selecting on the wall the most interesting points, a process based only on the experience of the geologist and aimed to find clear decay processes and relevant alteration. The idea at the base of this processing was the possibility to "bring away" a very detailed sample of the stone surface without any need to damage the original wall. At the same time, it was formulated the idea to act a monitoring over this spot of interest. The tools and processing for this phase are exactly the same used for the photogrammetry of the artworks, with the main difference of using a specific tripod head (to allow a proper movement of the camera at close distance) and a series of masks to evidence the sample and make easyer the reconstruction process. The high level of detail of the sample gives the possibility to check and verify very minimal difference between two models. Repeating the sampling in time it is possible to hypothesize an accurate check of the ongoing decay and transformation of the surface.

\section{CONCLUSIONS}

The interdisciplinary research, carried out through geological investigations, together with the 3D digital survey and the micro-photogrammetry, allowed to obtain important information to know, on the one hand, the composition, origin and alteration of the volcanic rocks used in the construction of the Cathedral of Sant'Antioco di Bisarcio, and, on the other hand, to precisely define the geometric and volume aspects of the architectural structure, useful both for define the construction phases of the building, and to understand the technical factors that may have influenced the choices of the designer/constructor.

The geochemical, mineralogical and petrographic analyzes on stone materials show above all a use of different pyroclastic rocks among the three main construction phases of the Cathedral (before and after the fire that led to the destruction of the first church before 1090). In fact, in the first building very varied local ashlars in terms of compositional characteristics and their size were used; these ashlars are usually less than $15 / 20 \mathrm{~cm}$ and they show an irregular shape, simply rough-hewn. Among these rocks are frequently found strongly welded ignimbritic facies (i.e. lava-like ignimbrites), more difficult to work in the medieval period. Given their good physical-mechanical characteristics, in general, these rocks are less altered than those used in the second and third phases for the subsequent construction phase of the XII century. These last pyroclastic rocks are less mechanically resistant; they are more homogeneous in compositional terms, even if they present a high chromatic variety. Given their regularity in the shape of the ashlars, more squared and well cut, and geochemical similarity with the volcanic stones outcropping near to the church, it is possible to assume that they come from a single quarry not far from the site (which at the moment has not yet been identified with precision); in fact, it is probable that today the vegetation has obliterated the fronts and the extraction cuts of the quarry.

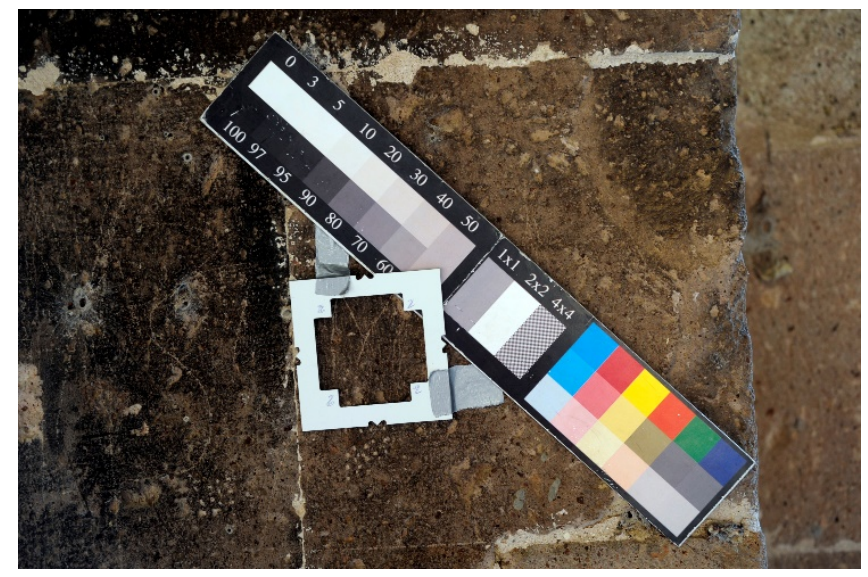

Fig. 8. One of the 10 samples from the materials micro-photogrammetry.

The pyroclastic rocks used in the second and third construction phases show a greater degree of chemicalphysical alteration compared to pyroclastites and ignimbrites used in the first construction phase. In some cases, these rocks show a very advanced physical decay in which one arrives at the undoing of the ashlars; in these cases, in the restoration interventions were replaced with new similar stone blocks.

The 3D digital survey on the monument, through laser scan technology, has allowed to highlight the structural and architectural features of the Cathedral of Sant'Antioco di Bisarcio, showing the technical level adopted in the three different construction phases. Moreover, the survey allowed to highlight the structural problems due, for example: parts of the walls weakly affected by out of lead, structural weakening in the stone structure points most stressed under the static profile.

Finally, the microfotogrammetry investigations have led to understand how the alteration processes are performed on the analyzed stone surfaces. Generally, the chemicalmineralogical process is slower than the process of physical decay induced by weathering, so it is easier to observe the physical processes on the surface (i.e., decohesion, exfoliation, flaking) with a consequent increase of porosity in the outside of stone substrate, thus facilitating the loss of material and the decorative works in the case of artistic elements (e.g., lion, capitals, bases, columns, corinas, etc.).

\section{ACKNOWLEDGMENT}

The geological survey (including the sampling of volcanic rocks from the outcrops and monument) was made in collaboration with Dr. Giuliana Lembo. The geochemical and petrographic investigations were made with help of Proff. Giampaolo Macciotta and Marco Marchi.

The digital survey first campaign was made in collaboration with Alessandro Peruzzi, Area3D SRL, Livorno. Post processing of the Digital Survey data: Giorgio Verdiani, Nunzia Stante, Giulia Tuccini.

\section{REFERENCES}

[1] F. Amadu, La Diocesi Medioevale di Bisarcio. Cagliari, 1963.

[2] P. Tola, "Codex Diplomaticus Sardiniae," op. cit., I, sec. XII, doc. IX, p. 183.

[3] R. Delogu, L'Architettura del Medioevo in Sardegna. Roma, 1953. 
[4] F. C. Casula, "Carte Reali Diplomatiche di Alfonso III il Benigno, Re d'Aragona," Riguardanti l'Italia, Padova, doc. 419, 1970, p. 238.

[5] S. Columbu, "Provenance and alteration of pyroclastic rocks from the Romanesque Churches of Logudoro (north Sardinia, Italy) using a petrographic and geochemical statistical approach," Applied Physics A, Materials Science and Processing, vol. 123(3), n. 165, 2017, doi:10.1007/s00339-017-0790-z.

[6] S. Columbu, A. M. Garau and C. Lugliè, "Geochemical characterisation of pozzolanic obsidian glasses used in the ancient mortars of Nora Roman theatre (Sardinia, Italy): provenance of raw materials and historical-archaeological implications," Archaeological and Anthropological Sciences, 2018, doi: https://doi.org/10.1007/s12520-018-0658-y.

[7] S. Columbu, A. Gioncada, M. Lezzerini and M. Marchi, "Hydric dilatation of ignimbritic stones used in the church of Santa Maria di Otti (Oschiri, northern Sardinia, Italy)," Ital. J. Geosci., vol. 133, pp. 149-160, 2014.

[8] S. Columbu, M. Palomba, F. Sitzia and M. Murgia, "Geochemical and mineral-petrographic studies of stones and mortars from the Romanesque Saccargia Basilica (Sardinia, Italy) to define their origin and alteration," Italian Journal of Geosciences, vol. 137, pp. 369 395, 2018, doi: https://doi.org/10.3301/IJG.2018.04.

[9] S. Columbu, G. Piras, F. Sitzia, S. Pagnotta, S. Raneri, S. Legnaioli, V. Palleschi, M. Lezzerini and M. Giamello, "Petrographic and mineralogical characterization of volcanic rocks and surfacedepositions on Romanesque monuments," Mediterranean Archaeology and Archaeometry, vol. 18(5), pp. 37-63, 2018, doi: 10.5281/zenodo. 1256051

[10] S. Columbu and G. Verdiani, "Digital Survey and Material Analysis Strategies for Documenting, Monitoring and Study the Romanesque Churches in Sardinia, Italy," Lecture Notes in Computer Science, Springer, vol. 8740, pp. 446-453, 2014.

[11] G. Macciotta, G. Bertorino, A. Caredda, S. Columbu, R. Coroneo, M. Franceschelli, M. Marchi and S. Rescic, "The S. Antioco of Bisarcio Basilica (NE Sardinia, Italy): water-rock interaction in ignimbrite monument decay," in Water-Rock Interactio (WRI-10), Cidu Ed., Swets \& Zeitlinger, Lisse, vol. 1, 2001, pp. 415-418.

[12] S. Columbu, A. M. Garau and C. Lugliè, "Geochemical characterisation of pozzolanic obsidian glasses used in the ancient mortars of Nora Roman theatre (Sardinia, Italy): provenance of raw materials and historical-archaeological implications," Archaeological and Anthropological Sciences, 2018, doi: https://doi.org/10.1007/s12520-018-0658-y.

[13] S. Columbu, and A. M. Garau, "Mineralogical, petrographic and chemical analysis of geomaterials used in the mortars of Roman Nora theatre (south Sardinia, Italy)," Italian Journal of Geosciences, vol. 136, pp. 238-262, 2017.

[14] S. Raneri, S. Pagnotta. M. Lezzerini, S. Legnaioli, V. Palleschi, S. Columbu, N. F. Neri and P. Mazzoleni, "Examining the reactivity of volcanic ash in ancient mortars by using a micro-chemical approach," Mediterranean Archaeology and Archaeometry, vol. 18(5), pp. 147$157,2018$.

[15] S. Columbu, F. Antonelli and F. Sitzia, "Origin of Roman worked stones from St. Saturno Christian Basilica (south Sardinia, Italy)," Mediterranean Archaeology and Archaeometry, vol. 18(5), pp. 17-36, 2018.

[16] M. Ramacciotti, S. Rubio, G. Gallello, M. Lezzerini, S. Columbu, E. Hernandez, A. Morales-Rubio, A. Pastor and M. De La Guardia, "Chronological classification of ancient mortars employing spectroscopy and spectrometry techniques: Sagunto (Valencia, Spain) Case," Journal of Spectroscopy, article ID 9736547, pp. 1-10, 2018, doi: 10.1155/2018/9736547.

[17] M. Lezzerini, S. Pagnotta, S. Columbu and G. Gallello, "Archaeometric study of mortars from the Pisa's Cathedral Square (Italy)," Measurement, vol. 126, pp. 322-331, 2018.

[18] S. Columbu, F. Antonelli, M. Lezzerini, D. Miriello, B. Adembri and A. Blanco, "Provenance of marbles used in the Heliocaminus Baths of Hadrian's Villa (Tivoli, Italy)," Journal of Archaeological Science, vol. 49, pp. 332-342, 2014.

[19] S. Columbu, F. Sitzia, and G. Ennas, "The ancient pozzolanic mortars and concretes of Heliocaminus baths in Hadrian's Villa (Tivoli, Italy)," Archaeol Anthropol Sci., vol. 9, pp. 523-553, 2017.

[20] S. Columbu, F. Sitzia, and G. Verdiani, "Contribution of petrophysical analysis and $3 \mathrm{D}$ digital survey in the archaeometric investigations of the Emperor Hadrian's Baths (Tivoli, Italy)," Rend. Fis. Acc. Lincei, vol. 26, pp. 455-474, 2015.

[21] M. Lezzerini, F. Antonelli, S. Columbu, R. Gadducci, A. Marradi, D. Miriello, L. Parodi, L. Secchiari and A. Lazzeri, "The documentation and conservation of the Cultural Heritage: 3D Laser Scanning and Gis Techniques for thematic mapping of the Stonework of the Façade of St. Nicholas Church (Pisa, Italy)," Inter. J. of Architectural Heritage: Conservation, Analysis, and Restoration, vol. 10, pp. 9-19, 2016.

[22] G. Verdiani and S. Columbu, "E.Stone, an archive for the Sardinia monumental witnesses," Lecture Notes in Computer Science, vol. 6436, pp. 356-372, 2010.

[23] L. Beccaluva, G. Bianchini, C. Natali and F. Siena, "Geodynamic control on orogenic and anorogenic magmatic phases in Sardinia and Southern Spain: Inferences for the Cenozoic evolution of the western Mediterranean," Lithos, vol. 180-181, pp. 128-137, 2011.

[24] M. Lustrino, L. Fedele, L. Melluso, V. Morra, F. Ronga, J. Geldmacher, S. Duggen, S. Agostini, C. Cucciniello, L. Franciosi and T. Meisel, "Origin and evolution of Cenozoic magmatism of Sardinia (Italy). A combined isotopic ( $\mathrm{Sr}-\mathrm{Nd}-\mathrm{Pb}-\mathrm{O}-\mathrm{Hf}-\mathrm{Os})$ and petrological view," Lithos, vol. 180-181, pp. 138-158, 2013.

[25] E. L. Advokaat, D. J. J. Van Hinsbergen, M. Maffione, C. G. Langereis, R. L. M. Vissers, A. Cherchi, R. Schroeder, H. Madani and $\mathrm{S}$. Columbu, "Eocene rotation of Sardinia, and the paleogeography of the western Mediterranean region," Earth and Planetary Science Letters, vol. 401, pp. 183-195, 2014.

[26] A. Cherchi and L. Montadert, "The Oligo-Miocene rift of Sardinia and the early history of the western Mediteranean basin," Nature, vol. 298, pp. 736-739, 1982.

[27] J. Dostal, C. Coulon and C. Dupuy, "Cainozoic andesitic rock of Sardinia (Italy)," in Thorpe, R.S. (Ed.), Andesites: orogenic andesites and related rocks, Chichester: J. Wiley \& Sons, 1982, pp. 353-370.

[28] J. Gattaceca, A. Deino, R. Rizzo, D. S. Jones, B. Henry, B. Beaudoin and F. Vadeboin, "Miocene rotation of Sardinia: New paleomagnetic and geochronological constraints and geodynamic implications," Earth and Planetary Science Letters, vol. 258, pp. 359-377, 2007.

[29] L. Lecca, R. Lonis, S. Luxoro, F. Melis, F. Secchi and P. Brotzu, "Oligo-Miocene volcanic sequences and rifting stages: a review," Per. Mineral., vol. 66, pp. 7-61, 1997.

[30] S. Columbu, "Provenance and alteration of pyroclastic rocks from the Romanesque Churches of Logudoro (north Sardinia, Italy) using a petrographic and geochemical statistical approach," Applied Physics A, Materials Science and Processing, vol. 123 (3), n. 165, 2017, doi:10.1007/s00339-017-0790-z.

[31] M. Franzini, L. Leoni and M. Saitta, "Revisione di una metologia analitica per fluorescenza-X, basata sulla correzione completa degli effetti di matrice," Soc. It. Min. Petrol. - Rendiconti, vol. 31(2), pp. 365-378, 1975.

[32] J. W. Criss and L.S. Birks, "Calculation methods for fluorescent Xray spectrometry empirical coefficients vs. fundamental parameters," Anal Chem, vol. 40, pp. 1080-1086, 1968.

[33] H. De La Roche, J. Leterrier, P. Grand Claude and M. Marchal, "A classification of volcanic and plutonic rocks using R1-R2 diagram and major element analysis. Its relation-ships with current nomenclature," Chem. Geol., vol. 29, pp. 183-210, 1980.

[34] M. Bini and S. Bertocci, Manuale di rilievo architettonico e urbano. CittàStudi, De Agostini, 2012, Torino.

[35] R. Thompson, Close-up and Macro: A Photographer's Guide, David \& Charles PLC; 2nd Revised edition edition, 2007.

[36] G. Guidi, L. Micoli, S. Gonizzi, M. Brennan and B. Frischer, "Imagebased 3D capture of cultural heritage artefacts," in Proceedings of the Digital Heritage Conference 2015, Institute of Electrical and Electronics Engineers (IEEE), 2015.

[37] M. R. Ghiara, R. Lonis, C. Petti, E. Franco, S. Luxoro and G. Balassone, "The zeolitization process of Tertiary oro-genic ignimbrites from Sardinia (Italy): distribution and meaning importance," Per. Mineral., vol. 66, pp. 211-231, 1997.

[38] G. Verdiani and S. Columbu, "The Romanesque Churches of Sardinia (Italy): Digital Documentation and Investigation on Their Construction Materials and Architectonic Aspects," in 20th AnnualMeeting of the European Association of Archaeologists, Istanbul, Turkey, 10-14 Settembre 2014, Archaeology \& Art Publications, vol. 1, 2014, pp. 247-247. 